\title{
Forvaltningens organisering og mediernes placering af det politiske ansvar
}

Peter Bjerre Mortensen lektor, Ph.d., Institut for Statskundskab, Aarhus Universitet

Under hvilke betingelser og i hvilket omfang bliver en minister stillet til ansvar i medierne for gode og ikke mindst dårlige sager inden for sin ressort? Dette spørgsmål om delegation og ansvar er både klassisk og aktuelt, men har ikke tidligere været genstand for systematisk empirisk analyse. Med udgangspunkt i et nyt datasæt, der bygger på en indholdskodning af samtlige avisartikler om DSB fra tre landsækkende aviser i perioden 1995 til 2007, giver denne artikel et bud på, hvordan denne problemstilling kan undersøges empirisk. Artiklen giver samtidig nogle svar på, i hvilket omfang og under hvilke betingelser forskellige trafikministre i denne periode er blevet stillet til ansvar i mediernes henholdsvis positive og ikke mindst negative dækning af forhold vedrørende DSB.

\section{Indledning}

Politik handler i betydeligt omfang om, hvem der kan tildeles skyld for problemer og svigt i den offentlige forvaltning, samt om hvem der kan tildeles ansvar for at få problemerne løst. Er forringelser i den kommunale hjemmepleje eksempelvis først og fremmest kommunens skyld, eller er det i virkeligheden regeringen, der udsulter den kommunale økonomi, og dermed ikke giver mulighed for at tilvejebringe de ressourcer, der er nødvendige for at yde en tilfredsstillende service? Og når medierne stiller skarpt på svigt i fødevarekontrollen, miljøkontrol- len, tilsynet med banksektoren eller forsinkede tog, er det så den pågældende styrelse eller statsvirksomhed, der får skylden, eller placeres ansvaret som hovedregel hos den relevante fagminister?

Listen af eksempler på sådanne større eller mindre sager, der i deres kerne alle handler om, hvem der har det politiske ansvar for et givet problem er lang. Men til trods for, at disse sager fylder meget i medierne, på Christiansborg og i den offentlige debat, ved vi meget lidt om dem. Det er på den ene side ofte blevet hævdet, men aldrig undersøgt (jf. Christensen m.fl. 2007, 143), at delegation af beslutningskompetence effektivt kan friholde en minister for politisk ansvar (se bl.a. Fiorina 1982; Voigt \& Salzberger 2002; Flinders 2008). På den anden side er der studier af vælgeradfærd, der på et mere aggregeret niveau tyder på, at regeringer stort set altid bliver holdt ansvarlige for upopulære og vigtige problemer uagtet, at der er gode argumenter for, at årsagen til problemet ligger uden for regeringens kontrol (se Hood 2002, 24-25). Konkret er spørgsmålet altså, om medierne, og i sidste ende vælgerne, altid vil placere ansvaret på Slotsholmen, eller om ministeren via den institutionelle indretning af forvaltningen kan distancere sig fra problemer og upopulære beslutninger?

Med udgangspunkt i et nyt datasæt, der bygger på en indholdskodning af samtlige avisartikler om DSB fra tre landsdækkende aviser i perioden 1995-2007, giver denne artikel et bud på, hvordan vi kan begynde at studere denne problemstilling om delegation og ansvar empirisk. Argumentet for at fokusere på mediernes ansvarsplace- 
ring er, at medierne i dag udgør den primære arena for den politiske kamp om at henholdsvis tildele og undgå skyld og ansvar for problemer og svigt (se eks. Jerit 2007). Det betyder, at artiklen på grundlag af dette datasæt vil belyse, i hvilket omfang trafikministeren ${ }^{1}$ bliver stillet til ansvar, når aviserne bringer enten gode eller dårlige nyheder om DSB? Hvorvidt ministeren i højere grad bliver stillet til ansvar i artikler, der fokuserer på problemer med DSB end $i$ artikler med et positivt fokus på forbedringer, m.v.? Om oprettelsen af DSB som selvstændig offentlig virksomhed i 1999 har medvirket til at beskytte ministeren, når medierne efterfølgende har berettet om problemer med DSB? Og hvad med ministre, der har siddet længe på posten - bliver de i højere grad stillet til ansvar i avisernes dækning end ministre, der er nye på posten?

Derudover giver det store antal avisartikler om DSB mulighed for at undersøge, hvad intensiteten og omfanget af kritisk medieopmærksomhed på DSB betyder for trafikministerens inddragelse $\mathrm{i}$ avisernes dækning af DSB. Bliver trafikministeren i højere grad stillet til ansvar i perioder med intensiv mediedækning? Sådanne perioder kan dække egentlige skandaler, mediestorme, ,sager" og lignende, men i denne artikel er fokus først og fremmest på, hvorvidt mediernes dækning af ministerens ansvar varierer med intensiteten og omfanget af mediedækningen.

\section{Forvaltningens organisering og mediernes place- ring af det politiske ansvar}

I Danmark er ministeren den politiske forvaltningschef, der som sådan har det øverste ledelsesmæssige ansvar for ministeriets virksomhed. I praksis er ministeren dog langt fra involveret i alle de afgørelser, der træffes inden for ministerens ressort (jf. Christensen m.fl. 2006). For det første kan der være tale om intern delegation, hvor ministeren delegerer myndighed til styrelser mv. Der kan for det andet være tale om ekstern delegation, hvor ministeren uddelegerer myndighed til selskaber eller selskabslignende konstruktioner. Et tredje eksempel er kommunalisering af en given opgave, hvorved ansvaret for opgavens løsning lægges ud til kommunale enheder. Endelig kan myndighedskompetencen også delegeres til et kollegialt organ helt uden for det ministerielle hierarki (uafhængige råd og nævn), ligesom man kan gennemføre en egentlig privatisering, hvilket repræsenterer de mest markante brud med ministerstyret.

Der kan være mange grunde til at igangsætte og gennemføre sådanne reformer (for en oversigt, se Greve 2000; Christensen \& Pallesen 2001; Voigt \& Salzberger 2002). Spørgsmålet i denne artikel er, i hvilket omfang intern henholdsvis ekstern delegation af togdriftsopgaven til DSB har beskyttet trafikministeren, når problemer og svigt i togdriften vækker nyhedsmediernes interesse.
På den ene side er det blevet hævdet, at: „... ministrene som politiske forvaltningschefer delegerer myndighed til styrelser, mv., fordi de derigennem kan undgå at blive gjort ansvarlige, dvs. kan opnå politisk ansvarsfritagelse“ (Christensen m.fl. 2006, 107; se også Hood 2002). På den anden side er det bemærkelsesværdigt, at der: „... ingen undersøgelser [foreligger] af, om selskabs- og virksomhedsformen i praksis afpolitiserer virksomheden... således at $\mathrm{fx}$ en minister effektivt bliver friholdt for politisk ansvar, hvis der opstår kritik af virksomheden" (Christensen m.fl. 2007, 143).

Det er altså et åbent spørgsmål, om forskellige former for delegation af formelt ansvar og beslutningskompetence også betyder de facto delegation af ansvar (skyld) i offentlighedens øjne, når der opstår problemer og ting går galt. Flere faktorer kunne tale for et afkræftende svar på det spørgsmål. For det første bygger argumentet på, at den, der får delegeret magt og ansvar er loyal over for ministeren, når enheden (styrelsen, virksomheden, m.v.) bliver genstand for offentlig kritik. Som påpeget af Hood (2002) er det ikke usandsynligt, at delegaten vil have en interesse $i$ at forsøge at tage æren for de gode ting, og kun modvilligt acceptere skylden for de dårlige. Det argument implicerer desuden, at det sandsynligvis er nemmere for ministeren at "slippe for" æren for de gode ting end at undgå skylden for de dårlige. For det andet har studier indirekte peget på, at delegation af ansvar ligefrem kan skabe øgede problemer for ministeren, idet delegaten $\mathrm{i}$ stedet for at trække skylden væk fra ministeren, i stedet genererer yderligere kritik, der smitter af på ministeren (se Ellis 1994). Sager om ministerfyringer synes at give flere konkrete eksempler på dette (se eks. Woodhouse 2004; Thompson \& Tillotsen 1999). Endelig kan der blandt den politiske opposition såvel som i medierne være en tendens til at fokusere på de mest højtprofilerede aktørers rolle i sagerne (Shoemaker \& Reese 1996; Brändström m.fl. 2010), og derfor vil der formodentlig være en tendens til, at ministerens rolle i de pågældende sager overvurderes.

Disse overvejelser leder ikke til entydige forventninger, men de peger på nogle dimensioner, der er værd at undersøge nærmere i den empiriske analyse af trafikministerens rolle i mediernes dækning af DSB. For det første, hvad er vinklen i mediernes dækning? Er der fokus på problemer eller forbedringer? For det andet, har det betydning for mediernes dækning, at DSB i 1999 bliver en selvstændig offentlig virksomhed? For det tredje, bliver en trafikminister, der har siddet længe på posten i højere grad stillet til ansvar i medierne end én, der har været minister i relativt kort tid? Og endelig skal det undersøges, om ministerens inddragelse varierer med sagernes intensitet og omfang. Alt andet lige vil det være mere belastende for ministeren, hvis han/hun især tildeles skyld 
og ansvar i perioder med intensiv kritisk mediedækning af DSB's virksomhed.

\section{Hvordan man kan undersøge ministerens rolle $i$ mediernes dækning af DSB}

I analysen af, hvorvidt ministeren kan organisere sig ud af negativ opmærksomhed, tages udgangspunkt i mediernes dækning. Der er flere grunde til at studere ministerens ansvarspådragelse med udgangspunkt i medierne. For det første har studier vist, at politikere generelt betragter mediedækning af politiske debatter som (næsten) afgørende for befolkningens holdningsdannelse (Jacobs m.fl. 1998, Herbst 1998). Dertil kommer danske vælgerundersøgelser, der klart viser, at medierne er danske vælgeres vigtigste kilde til information om politikere, partier og politiske begivenheder (Andersen 2007; Buch \& Levinsen 2007, 65-66). Tilsammen udpeger disse og mange andre studier medierne som (d)en central(e) arena for den politiske kamp om at henholdsvis tildele og undgå skyld og ansvar for problemer og svigt (se også Jerit 2007; Hjarvard 2008).

Konkret i forhold til mediernes dækning benyttes den elektroniske artikeldatabase Infomedia, der indeholder flere avisers artikler i fuldtekst. Fordelen ved Infomedia er, at man kan foretage præcise stikordssøgninger, hvilket blandt andet gør det praktisk muligt at identificere de relevante artikler i forhold til undersøgelsens problemstilling. Det har omvendt den begrænsning, at de elektroniske medier (internet, radio og TV) ikke indgår i undersøgelsen, men det vurderes at være mindre problematisk i lyset af tidligere undersøgelser, der har vist et betydeligt overlap mellem dagbladenes valg af nyheder og de elektroniske mediers (se Lund 2000, 145; Vasterman 2005, 521).

Ikke alle dagblade er inkluderet i Infomedia-databasen og de, der er, er blevet inkluderet på forskellige tidspunkter. De eneste aviser, der indgår med artikler i fuldtekst i hele perioden fra 1. januar 1990 og frem til i dag er Politiken, Berlingske Tidende og EkstraBladet. For at styrke sammenligneligheden over tid afgrænses analysen til kun at se på disse tre avisers dækning af DSB. Samtidig sikrer netop de tre aviser tilsammen en vis afbalancering i forhold til at inkludere aviser af forskellig politisk observans (se Hjarvard 2008). Desuden vælges det at afgrænse undersøgelsesperioden til 1. januar 1995 til 31. december 2007. Den periode sikrer dels mange artikler både før og efter virksomhedsoprettelsen i 1999, dels at det ikke blot bliver en analyse af en enkelt minister eller en enkelt regering. ${ }^{2}$

Efter søgninger på ordet „DSB“ i de tre landsdækkende aviser blev et stort antal artikler kodet som irrelevante, fordi det viste sig, at selvom ordet DSB indgik i artiklen, handlede den i virkeligheden om noget andet. De relevante artikler blev derefter kodet manuelt af studentermedhjælpere efter forudgående optræning og på baggrund af en udførlig kodebog. Først blev den dominerende vinkel i artiklen kodet henholdsvis positiv, negativ eller neutral. Negative artikler handler eksempelvis om togforsinkelser, utilfredse passagerer, bod til DSB, utilfredse DSB medarbejdere, problemer med asbest i gamle tog, problemer i DSB's økonomistyring, m.v. Som positive artikler kodes omvendt artikler, der eksempelvis fokuserer på, at DSB har fået reduceret togforsinkelserne, at DSB har vundet en licitation, forbedret ledelse/økonomistyring i DSB, serviceforbedringer i DSB, osv. Neutrale artikler er dels artikler, der ikke meningsfuldt kan kodes som enten positive eller negative samt artikler, der eksempelvis bekendtgør, at der er indført rygestop i togene, refererer at køreplanen er blevet ændret, osv.

Derudover blev der for alle de negative og positive artikler kodet om der i artiklen blev placeret et ansvar, og hvis der blev placeret et ansvar, blev disse artikler kodet, med henblik på, hvem der i artiklen hovedsageligt får skylden for det pågældende problem henholdsvis æren for de beskrevne forbedringer. Mest interessant i nærværende artikel er fordelingen af avisartikler, hvor ansvaret placeres hos henholdsvis DSB eller Trafikministeren. Tabel 1 nedenfor giver et overblik over kodningerne af artiklerne. Fordelen ved det store antal avisartikler om både større og mindre sager er, at det øger tilliden til, at vi finder nogle mere generelle sammenhænge, som ikke blot drives af mere eller mindre unikke aspekter ved en given sag.

\section{Resultat af analysen}

Tabel 1 viser fordelingen af avisartikler om DSB opgjort for henholdsvis vinklen i artiklen samt den gennemsnitlige andel af artikler, hvori hovedansvaret placeres hos henholdsvis DSB eller trafikministeren. Tabellen bekræfter for det første den såkaldte negativitetsbias i mediernes dækning, som også er påvist i tidligere mediestudier (se eks. Soroka 2006). I gennemsnit er der således tre negative artikler om DSB for hver gang, der er en positiv artikel. Et forhold, der synes at støtte antagelsen om, at hensynet til at undgå skyld og ansvar for afdækkede problemer og svigt formodentlig vejer tungere end hensynet til at kunne tage æren for de relativt få historier om forbedringer og positive tiltag, som fanger mediernes opmærksomhed på et område som dette. Derudover er det i Tabel 1 værd at bemærke, at ansvaret placeres hos DSB i langt de fleste artikler (63,6 procent), og kun i godt 6 procent af artiklerne bliver ansvaret placeret hos ministeren. Det er således gennemsnitligt set en relativt lille del af artiklerne, der placerer hovedansvaret hos trafikministeren. Det støtter den grundlæggende antagelse 
Tabel 1. Oversigt over antal kodede avisartikler om DSB

\begin{tabular}{|l|c|}
\hline Samlede antal avisartikler om DSB & 5140 \\
\hline Heraf antal avisartikler kodet: & 2425 \\
Negative & 925 \\
Positive & 1790 \\
\hline Neutrale & $63,6 \%$ \\
\hline Procent af negative og positive artikler, hvor & $6,1 \%$ \\
DSB får hovedansvaret & \\
Trafikministeren făr hovedansvaret & \\
\hline
\end{tabular}

Note: Artikler om DSB i EkstraBladet, Politiken og Berlingske Tidende 1. januar 1995 til 31. december 2007.

om, at ministerens delegation af ansvar i vidt omfang også indebærer en de facto forskydning af ansvaret i mediernes dækning af de sager, der opstår.

Den øverste del af Tabel 2 viser, at avisernes ansvarstildeling afhænger af, om der er fokus på problemer og svigt (negative artikler) eller på forbedringer i DSB's drift og virksomhed (positive artikler). I de artikler, hvori der placeres et ansvar får ministeren hovedansvaret i godt 7 procent af de negative artikler imod kun 2,5 procent af de positive artikler. Der er altså en temmelig klar tendens til, at ministeren i højere grad får ansvaret for problemer og svigt end for forbedringer og positive tiltag. I den nederste del af Tabel 2 sammenlignes mediernes ansvarsplacering før og efter tidspunktet for DSB's omdannelse til selvstændig offentlig virksomhed. En vigtig begrundelse for reorganiseringen var, at DSB måtte frigøres fra den politiske beslutningsproces med henblik på at kunne handle på markedsvilkår. Som selvstændig offentlig virksomhed ledes DSB af en bestyrelse og direktion og bliver betalt af Trafikministeriet for at køre jernbanetrafik. Det sker på grundlag af en trafikkontrakt, der blandt andet specificerer kvaliteten og omfanget af den kørsel, som DSB skal udføre. Ifølge Tabel 2 har omdannelsen dog ikke ført til mere beskyttelse af ministeren i mediernes dækning af DSB. Hvor ca. 5 procent af alle de avisartikler om DSB, hvori der blev placeret et ansvar, før virksomhedsdannelsen i 1999 placerede hovedansvaret hos trafikministeren, gælder det samme for ca. 6,5 procent af artiklerne efter reorganiseringen. En forskel, der på trods af det store antal avisartikler ikke er statistisk signifikant. Det gælder

Tabel 2. Ansvarstildeling i avisartikler om DSB, procent

\begin{tabular}{|c|c|c|c|}
\hline & Negative artikler $(\mathrm{A})$ & Positive artikler (B) & Difference $(A-B)$ \\
\hline \multicolumn{4}{|l|}{ 1. Trafik/transportministeren } \\
\hline får hovedansvaret & 7,1 & 2,5 & $4,6^{*}$ \\
\hline 2. DSB får hovedansvaret & 63,8 & 62,5 & 1,3 \\
\hline \multirow[t]{2}{*}{$\mathrm{N}$} & 2352 & 642 & \\
\hline & $\begin{array}{l}\text { Efter DSB bliver selvstændig } \\
\text { offentlig virksomhed }(A)\end{array}$ & $\begin{array}{l}\text { Før DSB blev selvstændig } \\
\text { offentlig virksomhed (B) }\end{array}$ & Difference $(A-B)$ \\
\hline \multicolumn{4}{|l|}{ 1. Trafik/transportministeren } \\
\hline får hovedansvaret & 6,6 & 5,5 & 1,1 \\
\hline 2. DSB får hovedansvaret & 63,3 & 63,8 & $-0,5$ \\
\hline $\mathrm{N}$ & 1635 & 1359 & \\
\hline
\end{tabular}

Note: Tallene angiver procent af de positive henholdsvis negative artikler om DSB hvori, der placeres et ansvar. Det vil sige, at artikler hvori, der ikke placeres et ansvar ikke er inkluderet i procentbasen.

* Statistisk signifikant forskel, $\mathrm{p} \leq 0,05$ 


\section{Figur 1. Procent af negative artikler om DSB, hvori Trafikminister Flemming Hansen får skylden}

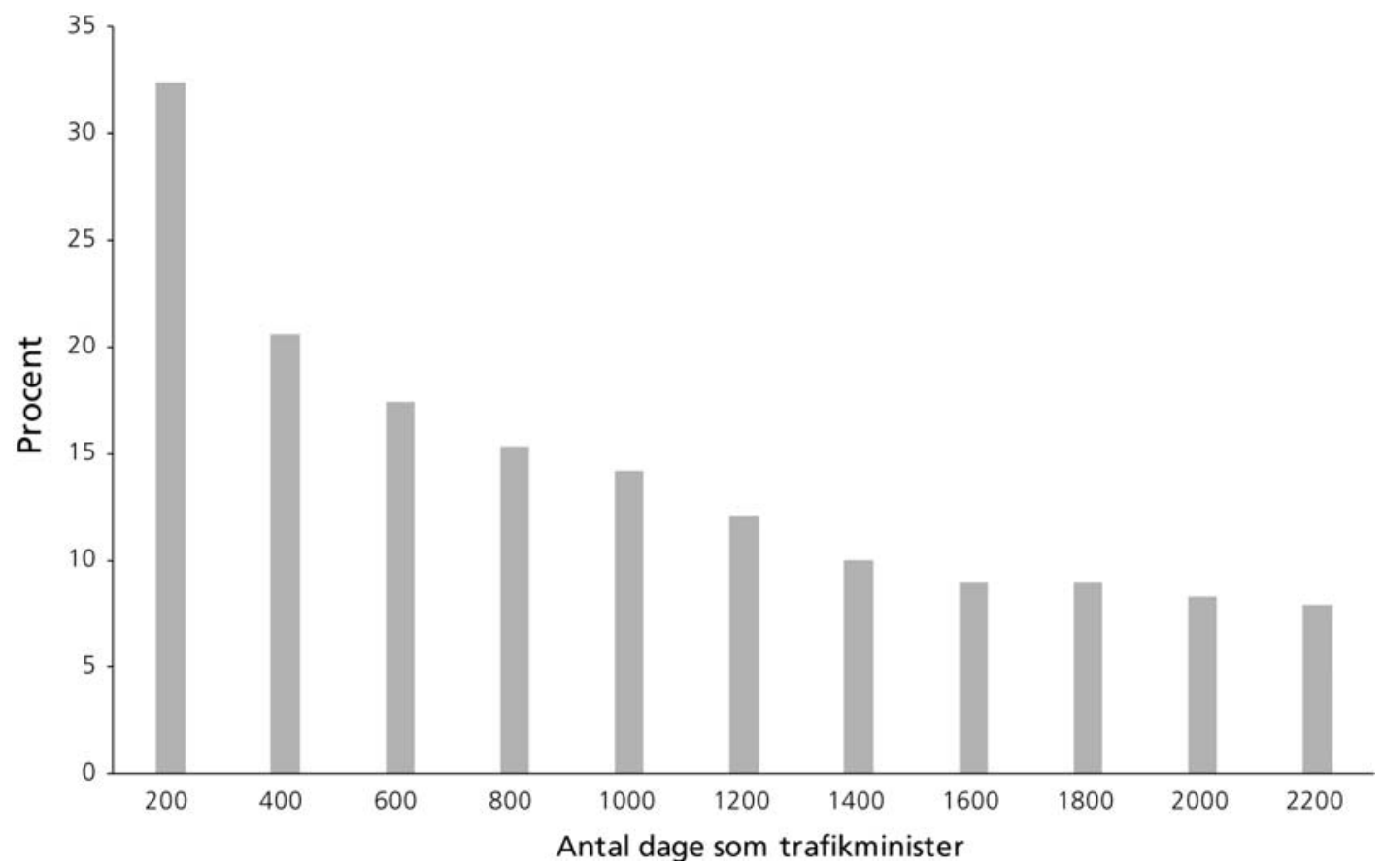

Note: Figuren angiver procentdelen af negative artikler, hvori Flemming Hansen tilskrives hovedansvaret opgjort efter 200 dage på posten, efter 400 dage på posten, osv.

også, hvis vi kun havde set på de negative artikler før og efter omdannelsen i 1999 (ikke vist i tabellen). Det gennemsnitlige antal artikler per år om DSB har været faldende siden 1999, men ministeren er gennemsnitligt blevet tilskrevet ansvar i nogenlunde samme omfang før og efter DSB blev omdannet til en statslig virksomhed.

Derudover tyder det ikke på, at problemer og sager i DSB i højere grad klæber til en minister, der har siddet længe på posten sammenlignet med en relativt nyudnævnt minister. Faktisk ser det generelt ud som om, at hvis der er en sammenhæng, er det den modsatte: desto længere tid på posten, jo mindre bliver ministeren stillet til ansvar i negative såvel som positive artikler om DSB. Det kunne afspejle, at ministre med tiden bliver mere driftssikre og dygtige til at distancere sig fra sager og problemer, men det dækker formodentlig også over at tiden, hvor nye ministre er fredet mod kritik i medierne er særdeles kortvarig i moderne politik. Flemming Hansen (K), der med i alt mere end 2100 dage som trafikminister, var den længst siddende på posten i den periode, vi her kigger på, er et godt eksempel på denne tendens. Som det fremgår af Figur 1, blev Flemming Hansen stillet markant mindre til ansvar i mediernes dækning af DSB i den sidste del af hans embedsperiode sammenlignet med den første del. I de første 200 dage på posten, fik Flem- ming Hansen skylden i godt 30 procent af de negative artikler om DSB, efter 400 dage var det tal faldet til godt 20 procent, hvorefter det faldt jævnt ned til godt 10 procent $\mathrm{i}$ alt mod slutningen af Flemming Hansens embedsperiode. Der kan naturligvis være flere forklaringer på denne udvikling, idet en række andre faktorer kan spille ind, når vi bryder data ned på enkeltministre. Om ikke andet giver resultaterne dog en klar indikation på, at der ikke er nogen entydig tendens til, at ministre med lang tid på posten per automatik tildeles mere ansvar i medierne end mere uerfarne ministre.

Figur 2 viser antal negative og positive artikler om DSB opgjort kvartalsvis i perioden 1. januar 1995 til 31. december 2007. I forhold til den før omtalte negativitetsbias føjer Figur 2 en yderligere nuance til denne observation, idet der tilsyneladende er en sammenhæng mellem andelen af negative artikler og omfanget af mediernes dækning. Hvor antallet af positive artikler ifølge Figur 2 er relativt stabilt, svinger antallet af negative artikler betydeligt over tid. Jo mere negativt fokus desto mere skrives der om DSB. Den massive dækning af DSB i 2006 dækker eksempelvis hovedsageligt sager om forsinkede tog, sporarbejde, opvarmede skinner samt problemer med indkøb af nye IC4-tog. 
Figur 2. Artikler om DSB kodet henholdsvis positive eller negative (kvartalsvis)

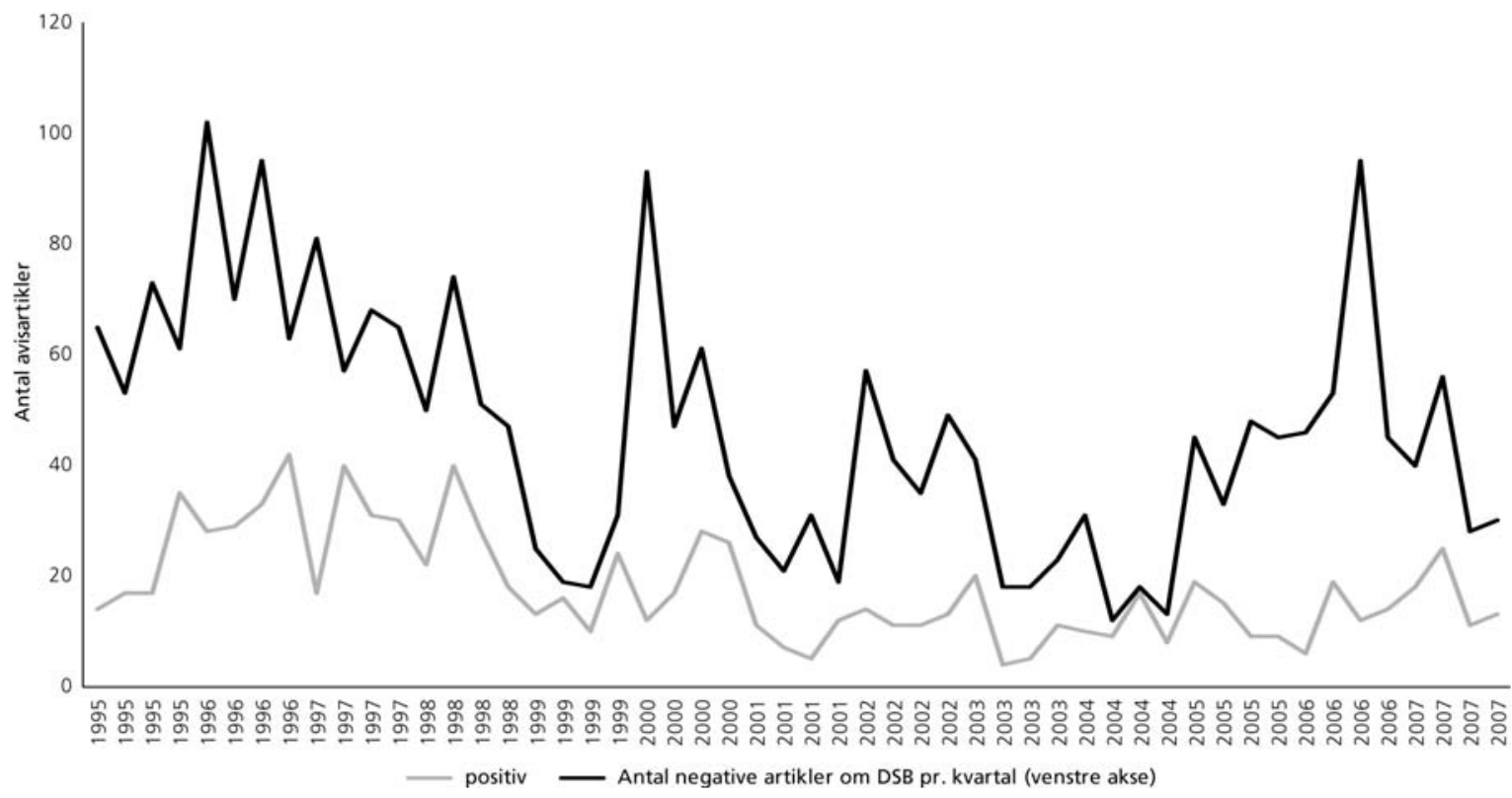

Note: Artikler om DSB i EkstraBladet, Politiken og Berlingske Tidende 1. januar 1995 til 31. december 2007.

Spørgsmålet er, hvor godt den organisatoriske indretning skærmer ministeren, når intensiteten i mediernes dækning tager til? Et umiddelbart svar på det spørgsmål giver Figur 3, hvori antallet af negative artikler om DSB opgjort per kvartal sammenholdes med procentdelen af negative artikler, hvori trafikministeren får hovedansvaret. Figuren viser for det første, at mediernes fokus på ministerens rolle og ansvar varierer over tid. Det er imidlertid ikke entydigt, at medierne i højere grad placerer ansvaret hos ministeren i perioder med intensiv mediedækning. Faktisk synes det som om, at de mediestorme, der har været i den sidste del af perioden i højere grad placerer ansvaret hos ministeren sammenlignet med perioden sidst i 1990'erne. Den iagttagelse støttes af en simpel korrelationsanalyse, der viser, at der efter 1999 er en statistisk signifikant positiv sammenhæng mellem antallet af negative artikler om DSB og procentdelen af negative artikler, hvori trafikministeren får hovedansvaret (korrelation $=0,21)$. Omvendt er denne sammenhæng negativ, men klart statistisk insignifikant for perioden før 2000 (korrelation $=-0,12)$. Om dette skyldes ændringer i de politiske forhold, de organisatoriske ændringer i relation til DSB, sagernes karakter eller mere generelle ændringer i mediernes vinkling og fokus, kan denne analyse ikke fortælle os. Det vi kan konstatere er, at DSB især i de senere år har fungeret som en bedre lynafleder for trafikministeren i perioder med relativt lav medieopmærksomhed, end i perioder med stor og negativ medieopmærksomhed. I takt med, at intensiteten i mediernes dækning stiger, kommer der relativt mere fokus på ministerens ansvar for problemer og svigt i relation til DSB's drift og virksomhed. Det synes at være en vigtig tilføjelse i forhold til, hvorvidt og ikke mindst under hvilke betingelser en minister kan distancere sig fra problemer og kritik i medierne ved at delegere ansvar og kompetence til offentlige virksomheder som DSB.

I forlængelse af det er det værd at bemærke, at ministerens inddragelse ifølge Figur 3 har skiftet markant fra kvartal til kvartal. Sådanne skift lader sig ikke umiddelbart forklare af de mere stabile variable, vi har fokuseret på i denne artikel. Til gengæld kunne disse udsving give anledning til at se nærmere på betydningen af mere sagsspecifikke karakteristika. Eksempelvis afspejler den store inddragelse af ministeren i 2002 i høj grad den sag, der opstod efter, at Arriva vandt udbuddet af togdriften i Midtjylland og dermed overtog et tidligere DSB domæne. Den afgørelse udløste nærmest en regulær krig i pressen mellem DSB og trafikministeren med gensidige beskyldninger om henholdsvis snyd og forskelsbehandling. Men udover at være en påmindelse om betydningen af mere 
Figur 3. Omfanget af kritisk mediedækning og placeringen af ansvar i medierne

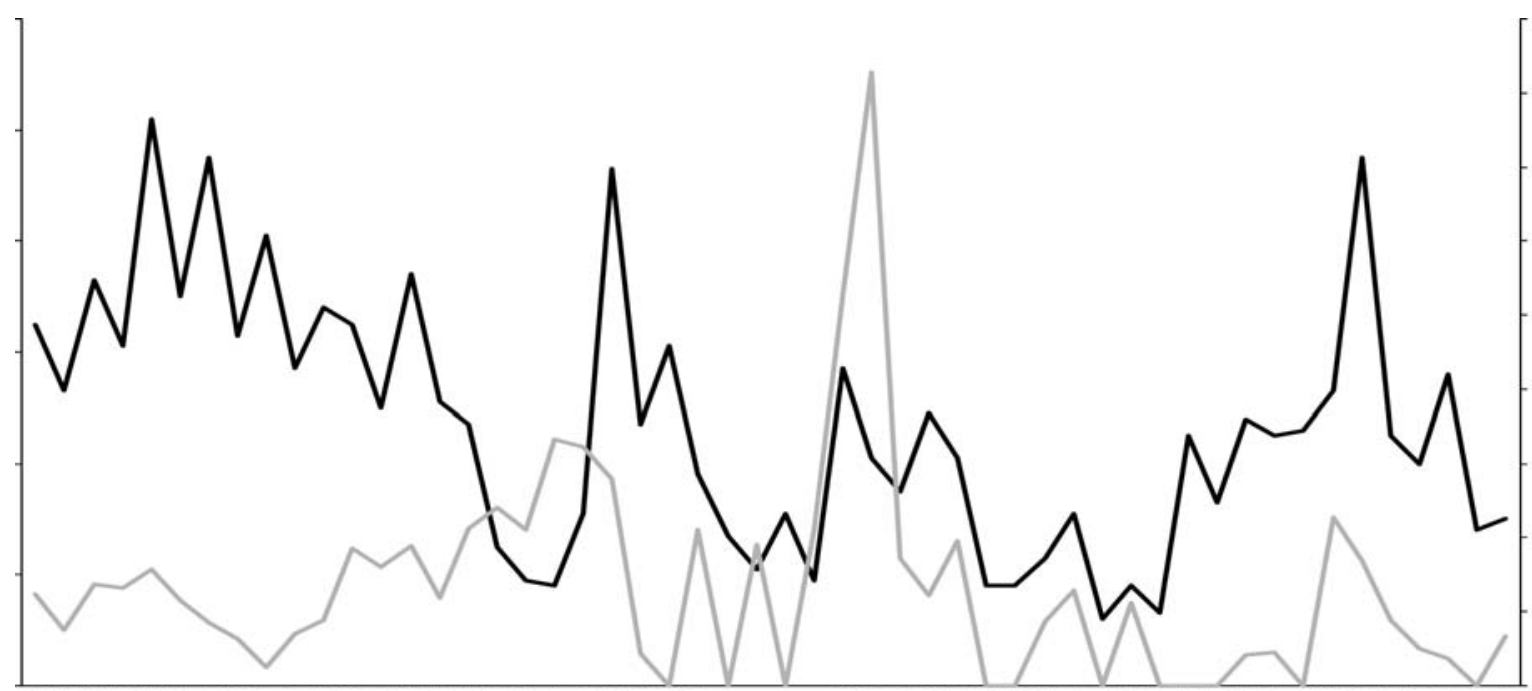

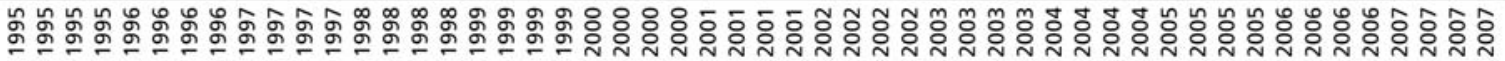

_ Antal negative artikler om DSB pr. kvartal (venstre akse)

_ Procent af negative artikler om DSB hvori ministeren får ansvaret (højre akse)

Note: Artikler om DSB i EkstraBladet, Politiken og Berlingske Tidende 1. januar 1995 til 31. december 2007.

idiosynkratiske sagsforhold er netop denne sag interessant derved, at den jo netop har sit udspring i omdannelsen af DSB til selvstændig offentlig virksomhed. Den omdannelse giver på den ene side ministeren og regeringen øget konkurrence på udbuddet af togtrafik i Danmark, men en del af prisen er tilsyneladende et mindre loyalt DSB, der i hvert fald i denne sag ikke gik af vejen for offentligt at optrappe en konflikt med trafikministeren. Og måske er et mindre loyalt DSB også en del af forklaringen på, at vi fandt en systematisk sammenhæng mellem omfanget af kritisk mediedækning og ministerinddragelse efter omdannelsen af DSB i 1999 men ikke før (jf. ovenfor).

\section{Konklusion}

Denne artikel har givet et bud på, hvordan vi empirisk kan begynde at undersøge en central og ofte fremført antagelse om, hvordan forvaltningens organisering afspejles i offentlighedens forståelse af, hvem der har det politiske ansvar, når ting går godt, og ikke mindst når ting går galt. På grundlag af et nyt datasæt om mediernes placering af ansvaret i sager vedrørende DSB i perioden 1995 til 2007, giver artiklen anledning til følgende konklusioner. For det første har analysen vist, at DSB i langt de fleste tilfælde får ansvaret i mediernes dækning, hvilket giver støtte til antagelsen om, at ministeren i vidt omfang $i$ offentlighedens øjne distanceres fra negative sager ved at uddelegere ansvar og kompetencer. Effekten er imidlertid asymmetrisk i den forstand, at ministeren i højere grad distanceres fra de gode sager end fra de dårlige sager. Og da sidstnævnte er i klart overtal, er dette en ikke uvæsentlig tilføjelse. Til gengæld synes omdannelsen af DSB i 1999 til en statslig virksomhed ikke i sig selv at ændre ved mediernes opfattelse af ministerens ansvar $\mathrm{i}$ sager vedrørende DSB. Ydermere svækkes DSB's lynaflederkvaliteter derved, at trafikministeren i hvert fald i de senere år i højere grad får skylden i perioder med stor medieopmærksomhed sammenlignet med perioder med lav medieopmærksomhed. Da andelen af negative artikler samtidig er forbundet med en stigning $i$ antallet af artikler, giver dette yderligere støtte til den asymmetriske effekt af delegation nævnt ovenfor.

Da denne analyse så vidt vides er den første af sin art, må konklusionerne nødvendigvis have en temmelig foreløbig karakter. For det første ved vi ikke, hvorvidt de identificerede effekter kan genfindes på andre forvaltningsområder. Mediernes dominerende negative vinkling er formodentlig temmelig universel, men det kan ikke udelukkes, at andre former for formel delegation af kompetence og ansvar virker anderledes end de former, der er undersøgt i denne artikel. De senere års liberaliseringer 
og reorganiseringer giver gode muligheder for at forfølge dette spørgsmål empirisk. Arbejdshypotesen vil dog være, baseret på den svage effekt af omdannelsen af DSB i 1999, at der skal temmelig markante reorganiseringer til, før vi ser en ændring i mediernes placering af det politiske ansvar.

For det andet er det oplagt at se nærmere på de relevante aktørers strategier og spil om at undgå ansvaret. Hvor loyale er eksempelvis ansatte og embedsmænd tilknyttet DSB, når ting går galt: giver de ministeren skylden, eller påtager de sig i vidt omfang ansvaret? Og hvad med ministeren: forsøger han/hun at tage æren for de gode ting og frasige sig skylden for de dårlige, eller vedkender de sig (delegationen af) ansvar i både gode og dårlige tider (jf. Ellis 1994; Hood 2002)? Dertil kommer andre relevante aktører, såsom politikere fra henholdsvis regering og opposition. Ifølge Brändström m.fl. (2004) vil oppositionen generelt forsøge at tale kritikken op ved at få placeret ansvaret så højt oppe i hierarkiet som muligt, imens regeringen og dens støtter generelt vil forsøge at tale konflikten ned ved at karakterisere problemer som tekniske, enestående og forårsaget af enkeltpersoner frem for systemfejl. Hvorvidt disse strategier gælder i praksis vil også kunne belyses ved viderebearbejdning af de typer mediedata, der ligger til grund for analysen i denne artikel.

Endelig kan man naturligvis ikke slutte fra mediernes placering af ansvaret for et givet problem, til at der drages politiske konsekvenser. I mange tilfælde vil stor, negativ medieopmærksomhed formodentlig være en nærmest nødvendig betingelse, men hvorvidt og ikke mindst hvornår det giver anledning til egentlige politiske konsekvenser såsom spørgsmål til trafikministeren i Folketinget, samråd i folketingsudvalgene og eventuelt egentlige ministerfyringer, er et empirisk spørgsmål. Det samme gælder, i hvilket omfang den bredere befolkning overtager mediernes vinkling og fremstilling i deres egen vurdering af den pågældende minister - noget der i et vist omfang lader sig belyse af de efterhånden mange survey målinger af ministres popularitet blandt vælgerne.

\section{Litteratur}

Andersen, Johannes (2007). „Medier, politisk interesse og viden om politik ", i Andersen, Jørgen Goul, Johannes Andersen, Ole Borre, Kasper Møller Hansen \& Hans Jørgen Nielsen (red.), Det nye politiske landskab. Folketingsvalget 2005 i perspektiv. Århus: Academica.

Brändström, Annika, Frederik Bynander and Paul 't Hart (2004). „Governing by looking back: Historical analogies and crisis management", Public Administration, 82, 1, 191-210.

Brändström, A., Kuipers, S. and Daléus, P. (2010). 'The Politics of Blame Management in Scandinavia after the Tsunami Disaster', i
A. Boin, P. 't Hart and A. McConnel (red.), Governing After Crises. Cambridge: Cambridge University Press.

Buch, Roger \& Klaus Levinsen (2007). „Nye kommuner, nye medier og borgernes syn på valgkampen“, i Buch, Roger \& Jørgen Elklit (red.), Nye kommunalvalg? Kontinuitet og forandring ved valget $i 2005$. Odense: Syddansk Universitetsforlag.

Christensen, Jørgen Grønnegaard, Erik Damgaard \& Jørgen Elklit (2007). Det demokratiske system. Valg, parlamentarisme og forvaltning. Århus: Academica

Christensen, Jørgen Grønnegaard \& Thomas Pallesen (2001). „The Political Benefits of Corporatization and Privatization“, Journal of Public Policy, 21, 3, 283-309.

Christensen, Jørgen Grønnegaard; Peter Munk Christiansen \& Marius Ibsen (2006). Politik og forvaltning. Gylling: Academica

Ellis, Richard J. (1994). Presidential Lightning Rods. Lawrence, Kansas: University of Kansas Press.

Fiorina, Morris (1982). „Legislative Choice of Regulatory Forms: Legal Process or Administrative process", Public Choice, 38, 33-66.

Flinders, Matthew (2008). Delegated Governance and the British State. Oxford: Oxford University Press.

Greve, Carsten (2000). Statens virksombeder. Aktieselskabsdannelse of privatisering i 1990'erne. København: Jurist- og Økonomforbundets Forlag.

Herbst, Susan (1998). Reading public opinion: How political actors view the democratic process. Chicago: University of Chicago Press.

Hjarvard, Stig (2008). En verden af medier. Medialiseringen af politik, sprog, religion og leg. Gylling: Samfundslitteratur.

Hood, Christopher (2002). „The Risk Game and the Blame Game“, Government and Opposition, 37, 15-38.

Jacobs, Lawrence R., Eric D. Lawrence, Robert Y. Shapiro \& Steven S. Smith (1998). „Congressional leadership of public opinion“, Political Science Quarterly, 113, 21-41.

Jerit, Jennifer (2007). „Issue Framing and Engagement: Rhetorical Strategy in Public Policy Debates", Political Behavior, 30, 1, 1-24.

Lund, Anker Brink (2000). Forst med det sidste - en nyhedsuge i Danmark. Århus: Ajour

Shoemaker, Pamela \& Stephen D. Reese (1996). Mediating the Message. Theories of Influences on Mass Media Content. New York: Longman

Soroka, Stuart N. (2006). „Good News and Bad News. Asymmetric Responses to Economic Information", Journal of Politics, 68, 2, 372385.

Thompson, Elaine \& Greg Tillotsen (1999). „Caught in the Act: The Smoking Gun View of Ministerial Responsibility", Australian Journal of Public Administration, 58, 1, 48-57.

Vasterman, Peter L.M. (2005). „Media-Hype: Self-Reinforcing News Waves, Journalistic Standards and the Construction of Social Problems“, European Journal of Communication, 20, 4, 508-530.

Voigt, Stefan \& Eli M. Salzberger (2002). „Choosing Not To Choose: When Politicians Choose To Delegate Powers", Kyklos, 55, 289-310.

Woodhouse, Diana (2004). „UK Ministerial Responsibility in 2002: The Tale of Two Resignations", Public Administration, 82, 1, 1-19.

\section{Noter}

1 Titlen har skiftet over tid, men betegnelsen Trafikminister dækker i denne artikel også Transportminister.

2 I perioden 1995-2007 har der været syv forskellige trafikministre. 